\title{
TANK Gene
}

National Cancer Institute

\section{Source}

National Cancer Institute. TANK Gene. NCI Thesaurus. Code C133880.

This gene plays a role in the inhibition of tumor necrosis factor receptor familydependent signaling. 